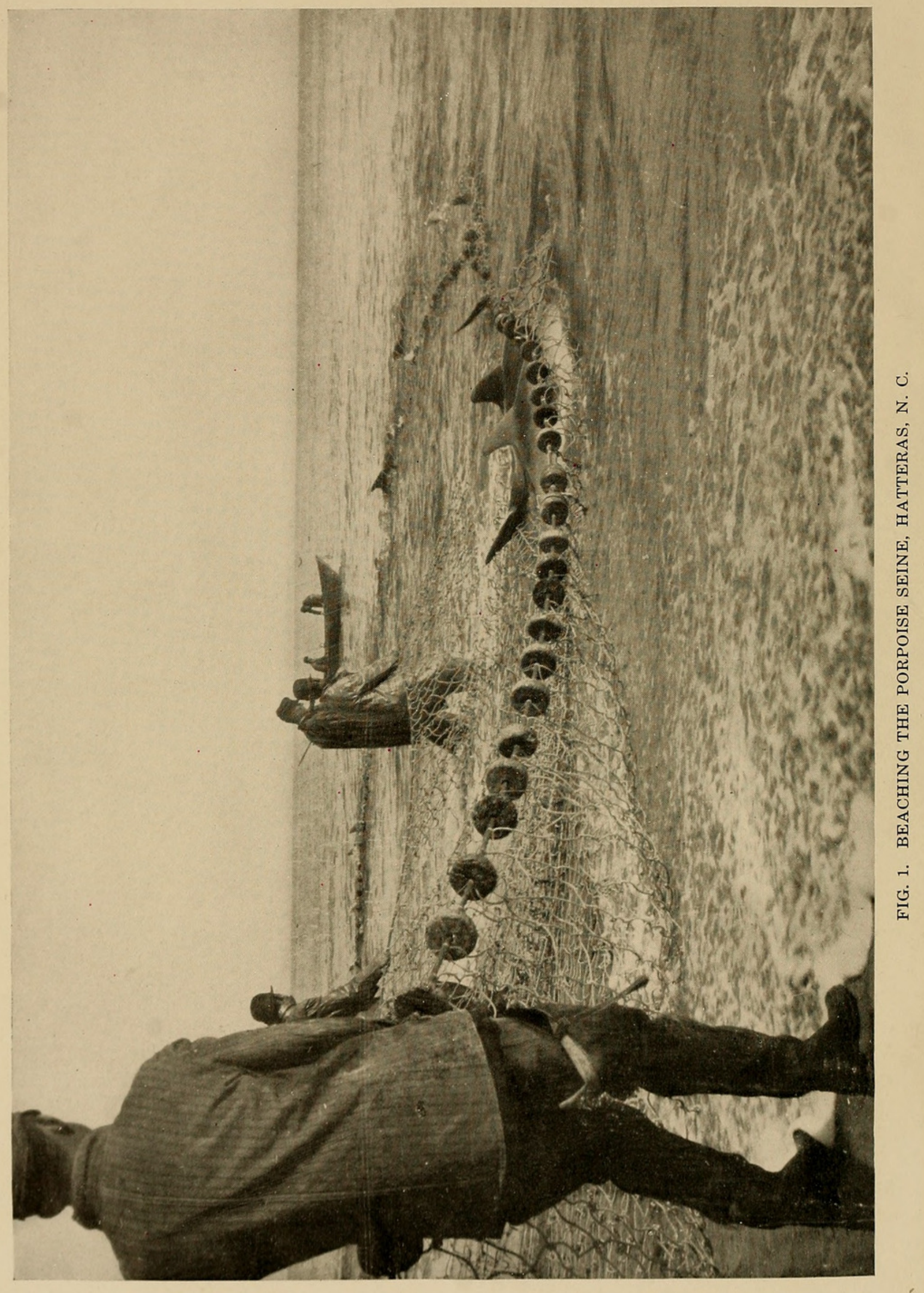




\title{
THE PORPOISE IN CAPTIVITY
}

\author{
By Charles Haskins Townsend, \\ Director of the New York Aquarium.
}

Illustrated with photographs by E. R. Sanborn and the Author.

The New York Aquarium has a school of porpoises and lays claim to the world's best single exhibit of captive wild animals. It is fascinating to have these lively rangers of the open ocean actually dwelling in our midst. They are the same "jolly porpoises" that make high speed dashes under the bows of ships. No more popular exhibition of wild life has ever been made anywhere. After seven months in a circular pool thirty-seven feet in diameter and seven feet deep, they remain in good condition, feeding, leaping and otherwise disporting themselves after the manner of porpoises on the high seas. There are five of them and their playful splashing throws showers of water over visitors who venture too close. The exhibit is unique, as there is no other Aquarium in America or Europe equipped with pools large enough to accommodate such animals.

Our specimens represent the so-called Bottle-nosed Porpoise, (Tursiops truncatus Montagu), and were captured at Cape Hatteras, North Carolina, about 400 miles south of New York, on November 12, 1913.

The captive porpoises are very lively and keep swimming day and night, rising to blow usually with each circuit of the pool. Being kept in shallow water, they probably breathe oftener than they would in deep water. They often swim under water, belly up, like seals, but never lie upon the bottom or bask at the surface as the latter do. Visitors ask whether they ever rest-a question not easy to answer. If they do, it is apparently without cessation of forward motion. Nevertheless they are quieter at night when most of the lights are cut off, and do not indulge in boisterous play. For a time two of them habitually moved from left to right, while three took the opposite course, but this practice soon became less regular and is appar- 
ently breaking up. Sometimes the speed is slow, but more often it is rather rapid. Occasionally they indulge in a bit of racing that makes high waves, the water surging up to the coping of the pool. A porpoise speeding around the pool can make a right-angled turn as quickly as a frightened fish, without lessening speed.

When being fed all regularity of movement is abandoned, and they rush in various directions to seize at the surface the fishes slowly thrown into the pool. This continues for some time after feeding, until all sunken scraps are gleaned from the bottom. All food is swallowed under water. Frequently a porpoise will play with a dead fish, thrusting its head clear of the water and throwing the fish from five to ten feet away, when it is recovered and thrown again. Such play may last half an hour, or until the fish is reduced to scraps too small to be thrown. It is not uncommon for two or three of them to be engaged in throwing fishes at the same time and the practice is becoming habitual.

Several times a day they indulge in very active play, darting with mock ferocity after each other, or leaping quite clear of the water and striking with heavy splashes. They often swim on their backs, with the jaws out of water, or on their sides repeatedly striking the surface with the head. When leaping a favorite trick is to throw the body around until the dorsal fin is forward, with a resulting splash that sends the spray quite out on the floor. A high leap by one of them is usually a signal that starts them all to leaping. Our fears that they might leap quite out of the pool were unfounded; they are clever enough to avoid the wall which surrounds them. Another game is played by going around the pool with short dives, each time striking the surface with the flat of the tail. When the pool is entirely full of water their play is livelier than when the water level is lowered. The increased depth gives them more confidence and they often turn complete forward and backward somersaults. The ordinary swimming motion of the tail is up and down, but, if playfully charged by a companion, the porpoise seems to make a spurt ahead by more or less side action of the tail. This is not easy to determine, however, and may be more apparent than real, as the water is too much dis- 
turbed by high speed dashes for accurate observation. The animal undoubtedly relies upon its tail for propulsion, the flippers or pectoral fins being brought into action in making turning movements. Several of the porpoises have lately taken to swimming on their backs, and the movements of the flippers and tail at such times is easily seen as contrasted with the white under parts. In swimming on the back, however, there is considerable lateral action of the tail.

Frequently three or four of them will bunch together in the center of the pool, rolling and rubbing against each other in a ball-like mass suggestive of the tussling of puppies. This may at times mean that they are merely scratching, as the single porpoise kept in the Aquarium for two and a half months last summer frequently rubbed his sides or back against the back of a large sturgeon kept in the same pool. This injured porpoise indulged in no play and swam day and night in the same circle from right to left, but always fed freely.

There is considerable mobility of the neck of the porpoise, an animal lacking all outward appearance of a neck. The head can be turned down at an angle of about 45 degrees to the body, and can be turned as far sideways with equal readiness. These motions can be seen at feeding time and when the animals are tossing fishes.

There is no evidence that the porpoise can see out of water. In throwing a fish the head is often thrust well above the surface, but the animal seems to be always intent on its plaything, entirely disregarding the visitors leaning over the rail five or six feet away. While a fish thrown into the water is promptly seized, the porpoise pays no attention to a fish suspended by a thread two inches above the surface. If the eyes of porpoises and other whales were fitted for observation above the surface of the water, as are the eyes of seals, they might long ago have learned to use them in the same way.

Porpoises instantly recognize any change that may occur in connection with the water level of the pool. The entirely noiseless opening of a distant valve to lower the water, is apparent to them and may stop their play temporarily. A pool only thirty-seven feet in diameter does not of course afford space for the high activity of which the porpoise is capable. Never- 
theless they often leap three feet or more clear of the surface, sometimes striking the water forcibly enough to throw spray thirty feet away and fifteen feet into the air. The visitor soon gets the impression that they enjoy life even in captivity and their keepers, while always vigilant as to their needs, have ceased to be concerned about their safety, regarding them as almost domesticated animals.

The naturally sociable and gregarious habit of porpoises is evider try not lessened by captiviy. Sometimes they seize each other by the back just behind the dorsal fin, but there are no tooth marks on any of them and it is probably done in play. The indications are that they are altogether amiable and inoffensive toward each other. The only species of porpoise destructive to its kind is the well-known "Killer" (Orca gladiator).

Our porpoises were observed mating in January, and again in March and April. It is possible that they will breed in captivity if their lives are not shortened by indoor life. The period of gestation is not known for any species of the whale order.

One of the five porpoises, put into the pool apparently uninjured, soon became deformed in the hinder portion of the body and cannot participate in the rough gambols indulged in by the others, keeping mainly to the outer circle of the pool. Its injuries are probably due to rough handling at the time of capture, as some of the porpoises were dragged away from the net with a rope tied around the tail. Its present appearance suggests two dislocations of the vertebrae back of the dorsal fin. This porpoise always swims slowly and is without doubt permanently crippled, yet it feeds as freely and oftens attempts to throw fishes as the others do.

The Bottle-nosed Porpoise (Tursiops truncatus) resembles Delphinus delphis, a species of porpoise or dolphin more abundant in the eastern Atlantic and in the Mediterranean than along our coast. It is somewhat larger and darker and has fewer but larger teeth, while the jaws present less of the beaked or "bottle-nosed" appearance of Delphinus. The latter is the dolphin known to the ancients, and has been caricatured by painters and sculptors since the very beginnings of art. The artists now have an opportunity to learn what the real dolphin looks like. 
All porpoises and dolphins belong to the large family Delphinidae, of the order of whales, and there are about fifty different species. The names porpoise and dolphin are to some extent interchangeable; the former is, however, usually applied to the short-jawed kinds. The name "bottle-nose" is inapt, as the nostrils of all such animals are on top of the head and usually placed as far back as the eyes. The name dolphin is also applied to a fish (Coryphaena) celebrated for its changing colors.

Porpoises and dolphins are found in all seas, and there are strictly fresh-water species inhabiting the Amazon, Ganges and other rivers. The porpoise of the muddy Ganges is a smalleyed species that is practically blind, and lives upon crustacea gathered at the bottom of the river. The porpoise-dolphin family includes the little white whale or beluga of the Arctic Seas, two living specimens of which were once exhibited at the New York Aquarium for a month or more. The Aquarium has also had two other porpoises, Delphinus and Legenorhynchus, both of which were cast ashore too badly injured to live more than a few weeks.

The food of marine porpoises is chiefly fish and squid, for the capture of which their numerous small teeth are well fitted. At Hatteras they are known to feed largely on squeteague or weakfish. The fact that sand has been found in the stomachs of porpoises, indicates that they sometimes feed at the bottom. They are air-breathing, warm-blooded mammals, bearing a single young, which is nourished on milk. They are really small toothed whales, living entirely in the water and are altogether helpless on land. Two previous attempts were made to bring porpoises from Hatteras to the Aquarium. Instructions for their transportation were prepared in detail, but the plans were not carried out by those to whom the shipments were entrusted. In the first instance all the animals, eight in number, died en route, as they were unfortunately carried without water in the shipping tanks, and could not survive the journey without the cooling and supporting medium of water. The next attempt, in April, 1913 when the same blunder was made, gave only slightly better results. Although covered with wet burlap, four of the six porpoises shipped died between Hatteras and Norfolk, 
Virginia. At the latter point the consignment was met by the Director of the Aquarium, who promptly filled the tank containing the two survivors with water. One of these animals died soon after reaching New York, but the other lived two and a half months, notwithstanding the fact that the heating it had undergone during the first stage of shipment resulted in injuries which eventually ended its career. While adult porpoises give no special signs of distress when carried dry, they become greatly heated and develop large blisters, which later become festering sores, extending through the blubber and into the flesh. Being adapted to a life in the water, to which they naturally radiate a great amount of heat, water is absolutely necessary for the control of the body temperature.

Believing that plenty of cool water would insure safety during transportation, the Director of the Aquarium went to Hatteras in November, 1913, to supervise personally the details of shipment, which, entrusted to others, had been disregarded. As far as the adult animals are concerned, the results of the trip have been satisfactory, but the five half-grown animals, brought at the same time, died soon after their arrival in New York. The adults, each about eight feet long, gave no trouble during shipment, while the young were exceedingly restless and continually bruised themselves by their struggles in the shipping tanks.

Porpoises are hot-blooded, blubber-covered mammals and give off so much heat that the water of the shipping tanks becomes actually warm, and must be replaced by cold water every five or six hours. Immediately after their capture at Hatteras, where they were brought to land with a large drag-seine, the porpoises were placed for twenty-four hours in a deep salt water pond just back of the ocean beach. Here they had an opportunity to recover somewhat from the fright of capture, and to rest in cool water. No chances whatever were taken in the matter of temperature. On the beach their natural warmth of body would no doubt have been greatly increased by the hot sunshine. The following day they were seined out of the pond and placed in the shipping tanks, which were then hoisted on board a schooner and at once filled with water. During the voyage through the fresh waters of Pamlico Sound and 
the Great Dismal Swamp Canal, the water in the tanks was changed whenever it became warm. After reaching the New York steamer at Norfolk the cooling of the porpoise tanks en route was greatly simplified by the use of the steamer's salt. water hose.

The shipping of porpoises alive is therefore a simple matter. The adult animals readily stand transportation, while the young do not. If carried in long, narrow boxes large enough to accommodate them without rubbing, and if kept supplied with sufficient cold water to support and cover them, they can be handled easily enough. There is probably no reason why a porpoise, under such conditions, should not be carried in a tank many times the two-days' journey from Hatteras to New York, although on a journey by rail the changing of the water would be difficult and expensive. While its temperature could be controlled by the use of ice, the water carried without changing would be seriously fouled, for two or three days. The question of food could be disregarded for a few days without injury.

Our porpoises are heavy feeders, the five consuming about ninety pounds of fresh fish a day. This quantity of food has kept them in good condition, apparently without loss of weight. For several days after their arrival they would eat nothing, but at the end of a week they began to take live fishes and, after having once started to feed, it was not difficult to get them to take dead fish. A few days of hunger brought them around, as it does in the case of the newly captured seal or sea lion. Their principal food is herring and tomcod purchased in the markets. The live crabs thrown to them at various times were quickly seized and much tossed about, but were not eaten.

The keeping of porpoises in captivity has presented some difficulties with the water supply, their excrement constantly discoloring the water. The pool cannot be drained empty and cleaned, like those used for seals, as stranded, and consequently frightened, porpoises beat the ground with their tails so violently that they would be injured by the daily emptying of the pool. The water is now being kept fairly clear by carrying extra pipe lines to the pool and greatly increasing the flow of water. The pool is supplied with the brackish and rather impure water 
pumped from New York Harbor, as it is not practicable to supply it with pure sea water from the Aquarium's large storage reservoir, on account of the fact that porpoises would rapidly discolor the stored sea-water which is so important to the health of the collection of marine fishes in the Aquarium. The necessity of keeping them in the water of the Harbor, and exhibiting them in a public exhibition room which has to be heated during the winter, makes it, of course, impossible to hold them under entirely favorable conditions, yet they are undoubtedly doing well. They could no doubt be kept for some time in fresh water, as is some times done with seals and sea lions, but they would eventually suffer from the lack of the salts contained in sea water. Porpoises, perhaps of this species, frequently enter the fresh waters of Pamlico Sound through the inlets southwest of Hatteras, and many species of marine porpoises make long journeys into the fresh waters of rivers.

The icy water pumped in winter from New York Harbor, generally lower than 40 degrees, Fahr., is much colder than seawater at Hatteras, and requires to be warmed to about 55 degrees. In summer this will not, of course, be necessary.

Cape Hatteras is the only point in North America where a porpoise fishery has ever been regularly conducted, and where such animals can be taken near the shore and beached with drag seines. The bottle-nosed porpoise winters off our South Atlantic coast and is quite common in the vicinity of Cape Hatteras during the fall, winter and spring months. Schools of porpoises may be seen passing every day just outside the surf. They are taken with a net of extra heavy twine, about one thousand feet long, which is placed about two hundred yards outside the line of surf and parallel with it. At each end there is a boat in waiting, ready to carry the haul lines directly ashore as soon as a band of porpoises has passed between the net and the surf. After the lines have been carried ashore the porpoises are considered fairly secure, for they do not often attempt to cross the haul lines, and even when they do, can usually be frightened back by having someone shake each line continuously while it is being hauled in. It requires considerable time to bring the ends of the big seine to, the beach, but even then some of the porpoises may get away by leaping over the net or 
attempting to dive under it. The former can be prevented to some extent by sending a boat to the outer curve of the net, which serves to keep the animals from charging against it. Some of those that attempt to dive underneath become enmeshed and, being air breathers, are soon drowned. Thirty-three porpoises were beached in the haul of the seine which provided our specimens.

Although porpoises have been taken at Hatteras for two hundred years, the fishery has been conducted in a somewhat desultory manner, and with but little capital invested. The greatest number taken in a single year appears to have been fifteen hundred. Porpoises are valuable for their jaw oil, hides and body blubber, the value of each being in the order given. The oil derived from the jaws represents the greater part of the value, being worth ordinarily twenty dollars a gallon, refined. It is extracted from the broad posterior branches of the lower jaw, and is universally used for the lubrication of watches, clocks and similarly delicate mechanisms. An attempt was made at the Hatteras fishery to utilize the carcasses of these animals for fertilizer, but, as the location is isolated, the question of fuel for the furnace proved too serious and the project was abandoned.

The bottle-nosed porpoise (Tursiops truncatus) is the only species of porpoise that has ever been taken at the Hatteras fishery. Our eight-foot specimens represent the average size. A number of animals were measured in November, however, which exceeded nine feet in length. The greatest length for this species at Hatteras is twelve feet, but this is altogether unusual. Measurements and weights taken in November show that a porpoise five and a half feet long weighs 100 pounds; six feet, 160 pounds; seven feet, 200 pounds; and eight feet, 300 pounds.

The movement of porpoises along the great beach which extends in a general southwesterly direction from Cape Hatteras is usually close to the surf. The bands appear to move in both directions. Residents of Hatteras are of the opinion that the majority of those in the vicinity of Hatteras Inlet move to the eastward, turning south from the Cape, whence they gradually swing back to the mainland. They have not, however, 
been followed away from the beach, and their winter movements are not known with certainty.

The roving bands of porpoises may number from a dozen to several hundred, and are present in that region from early in October to early in May, when the majority of them move northward. This is by far the commonest of the eight or nine species of porpoises found in summer along the North Atlantic coast of the United States. The species is one that is widely distributed, occurring in many parts of the North and South Atlantic and the Mediterranean, and may even be abundant at other Atlantic points in winter, as well as at Hatteras. It has also been recorded from the Indian Ocean and the vicinity of New Zealand.

The writer participated in the capture of sixty-three porpoises in a single day at Hatteras, and, as the animals were still passing, it is likely that the fishermen could have obtained many more by throwing out the net a third time. The two sexes occur in about equal members. An examination of fiftyone specimens on November 12 showed a preponderance of females, there being thirty-four females and seventeen males but there is much variation in this respect according to the season. In the spring all classes of young and old may be found in the same bands, while in the fall a band may consist chiefly of one class. Although there were no porpoises present having a length of much less than five feet, these were probably the nursing young, although their teeth had already appeared. All of the females examined were in milk, and the females killed were not only in milk but also contained young. Whether there were still smaller animals, which might have slipped between the meshes of the net, could not be ascertained, but the indications are that the porpoises five feet in length represented the only young then with the herds, and were still nursing.

Females containing young are found in every catch from October to May. As porpoises are not taken in summer, there is no information relative to their condition at that season. On April 30, 1914, a fœtus was found "nearly four feet long," while other females killed the same day contained none over eighteen inches long. The period during which the young are brought forth, evidently covers several months. 
The appearance of the unborn young is well shown on plates 11 and 12.

According to the statements of the Hatteras fishermen the young porpoise nurses while the mother floats on her side; when very young it swims just ahead of the mother, and is raised to the surface by her each time she rises to breathe.

If our porpoises live long enough to breed in captivity, our knowledge of whales in general and porpoises in particular will be materially increased.

The specimens now in the Aquarium were presented on the beach at Hatteras, by Mr. Joseph K. Nye, of New Bedford, Mass., the proprietor of the fishery. They were transported at the expense of the New York Zoological Society.

The writer is indebted to Mr. Nye, and to Mr. W. H. Rollinson, manager of the fishery, for the statistics of the catch presented herewith.

STATISTICS OF THE HATTERAS PORPOISE FISHERY

FROM 1907 TO 1914.

$\begin{array}{lrlr}\text { Year } & \text { Catch } & \text { Year } & \text { Catch } \\ 1907 & 70 & 1911 & 826 \\ 1908 & 591 & 1912 & 4 \\ 1909 & 1550 & 1913 & \\ 1910 & 1278 & 1914 & \end{array}$




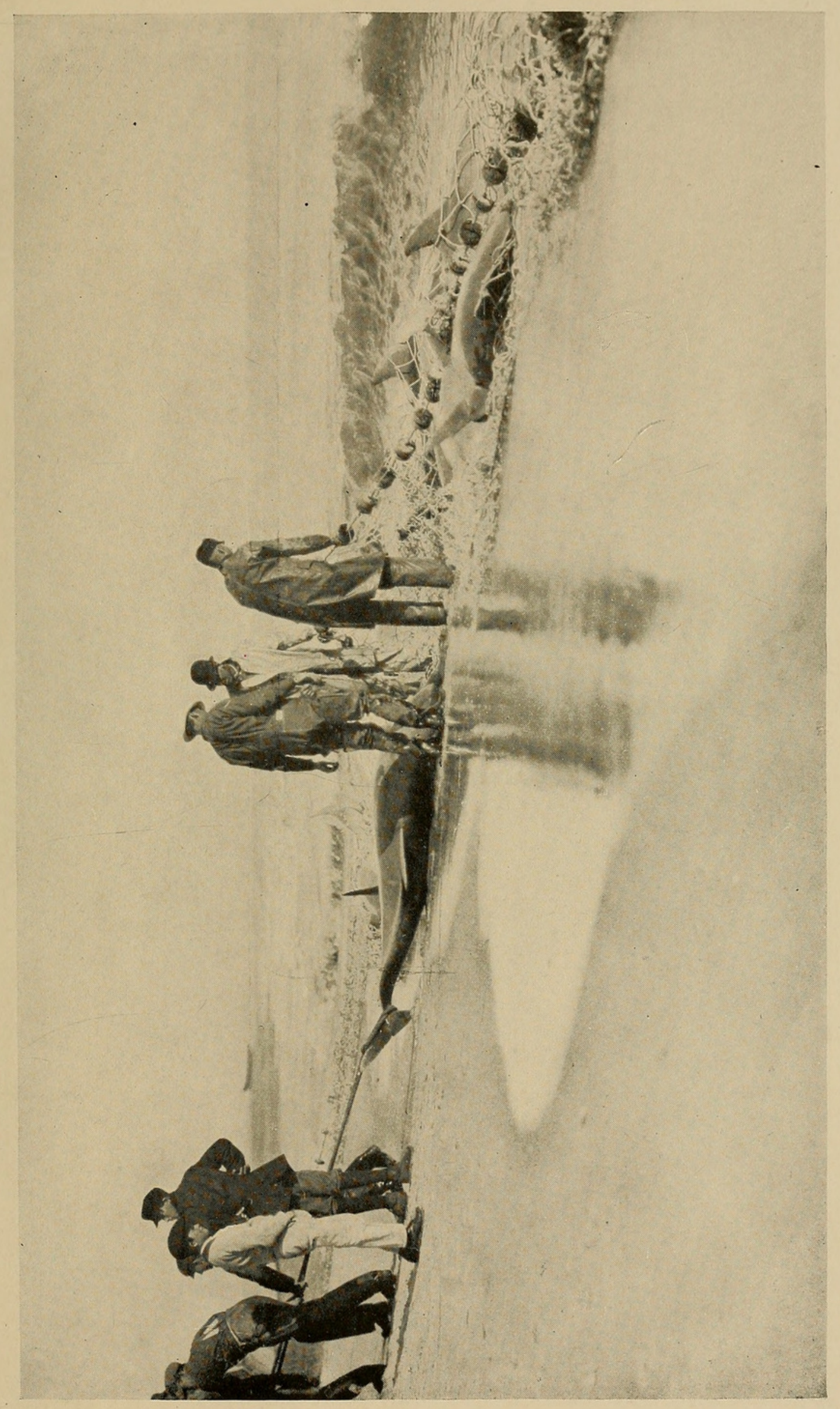

ב⿱ 


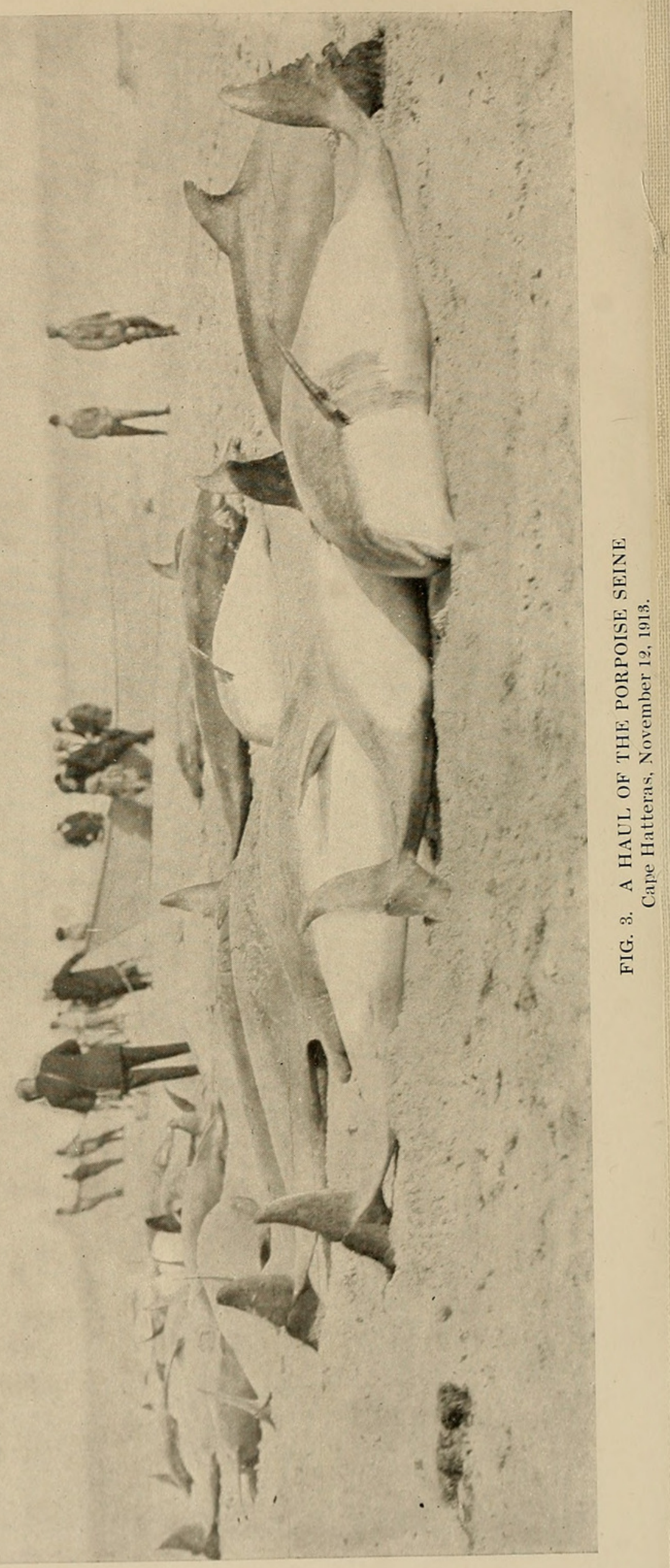




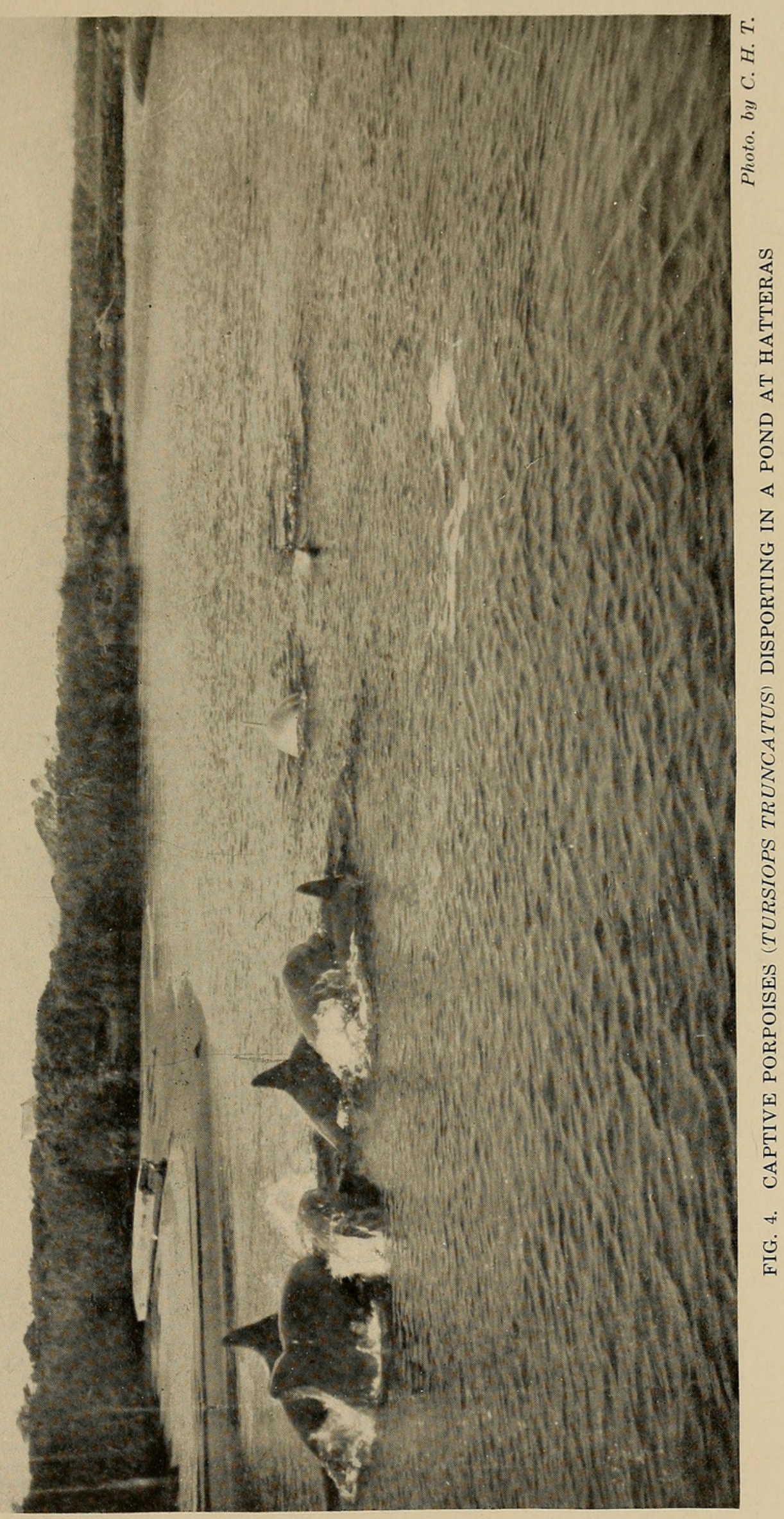




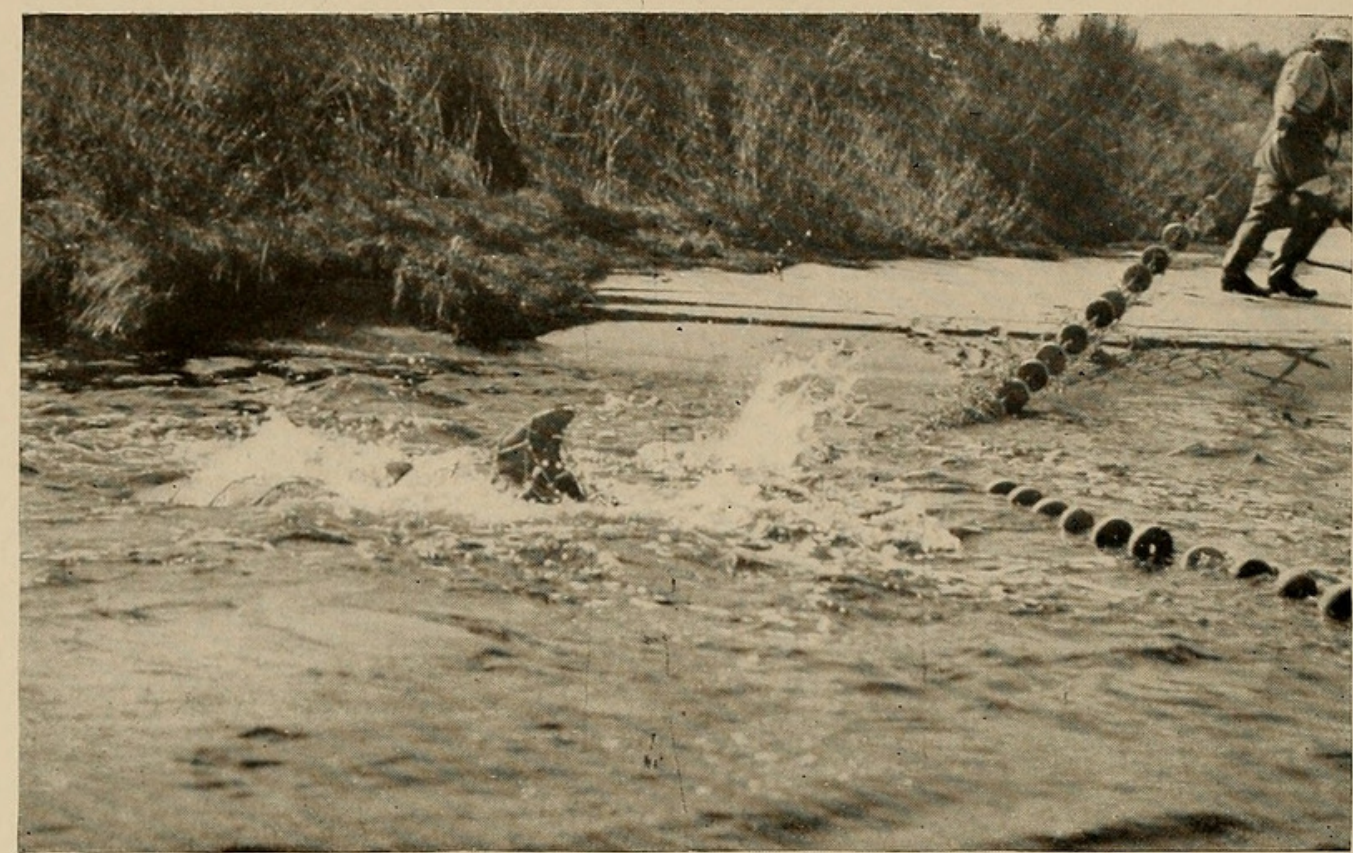

FIG. 5. RECAPTURING THE PORPOISES IN THE SALT-WATER POND

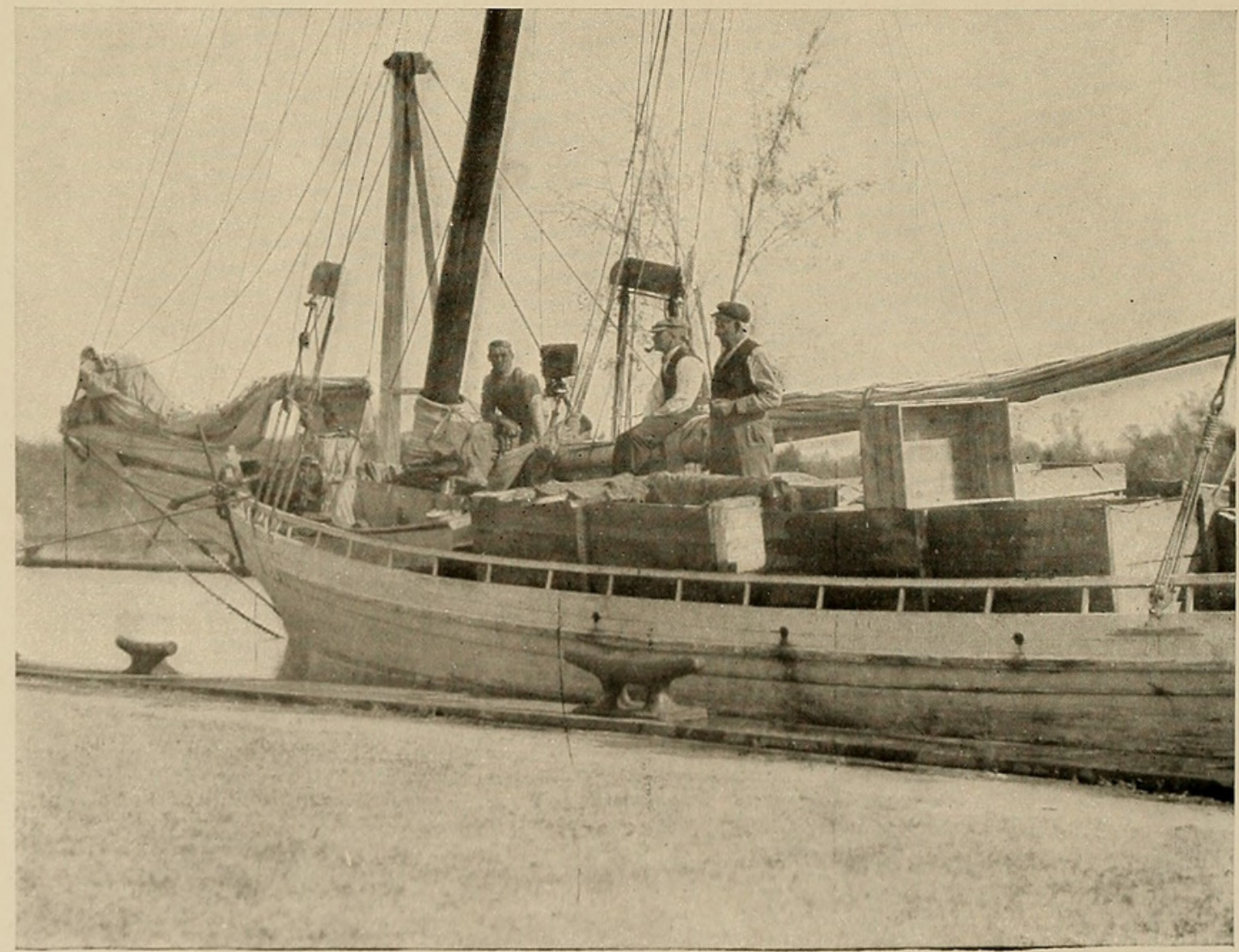

FIG. 6. A DECK LOAD OF PORPOISE TANKS: DISMAL SWAMP CANAL 


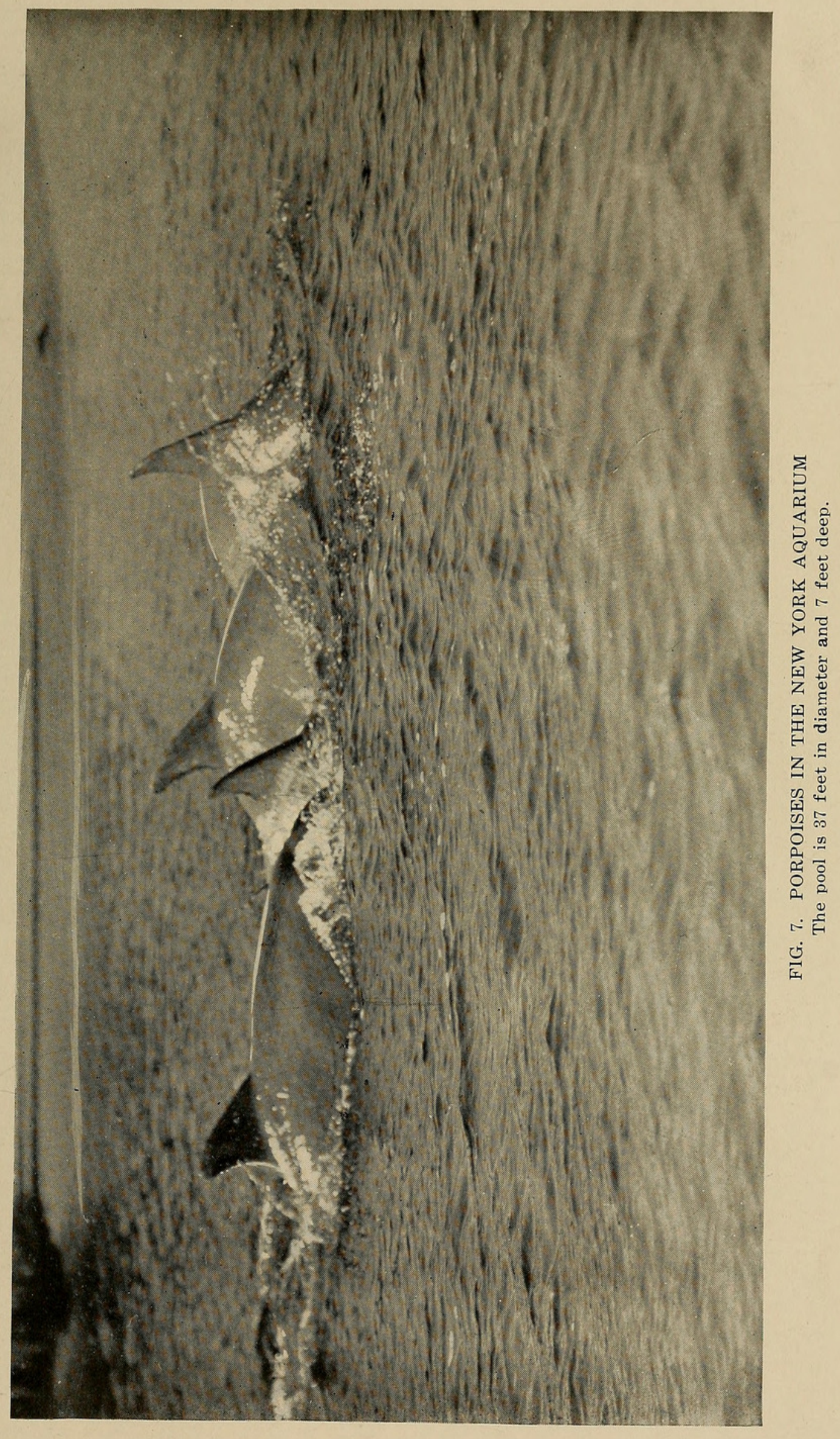




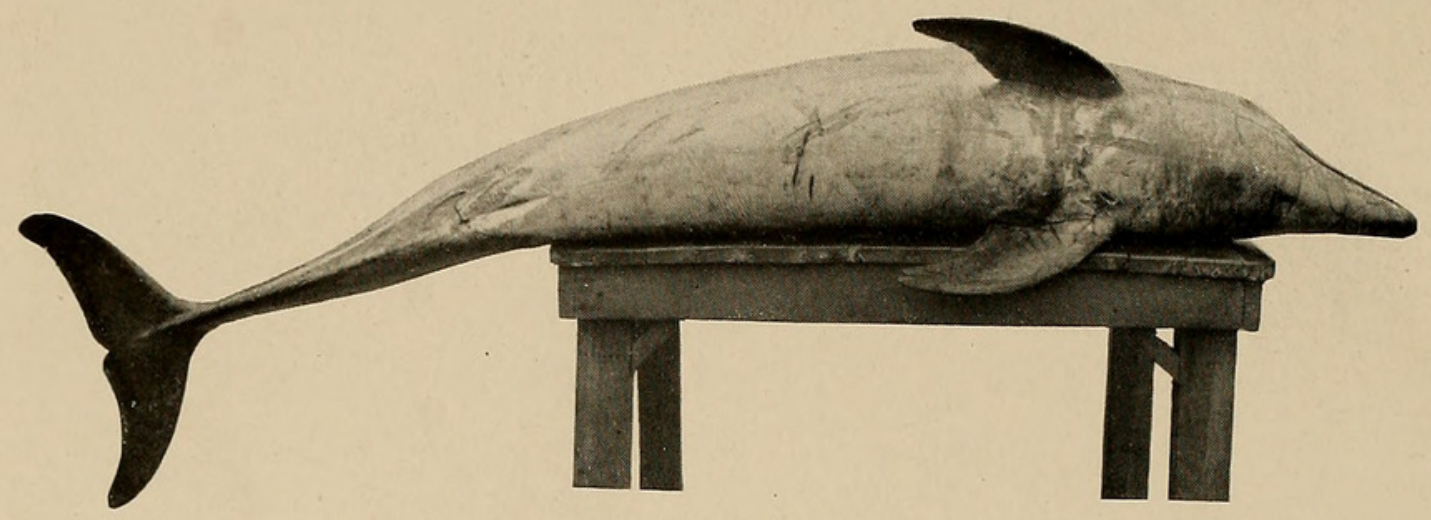

FIG. 8. TURSIOPS TRUNCATUS

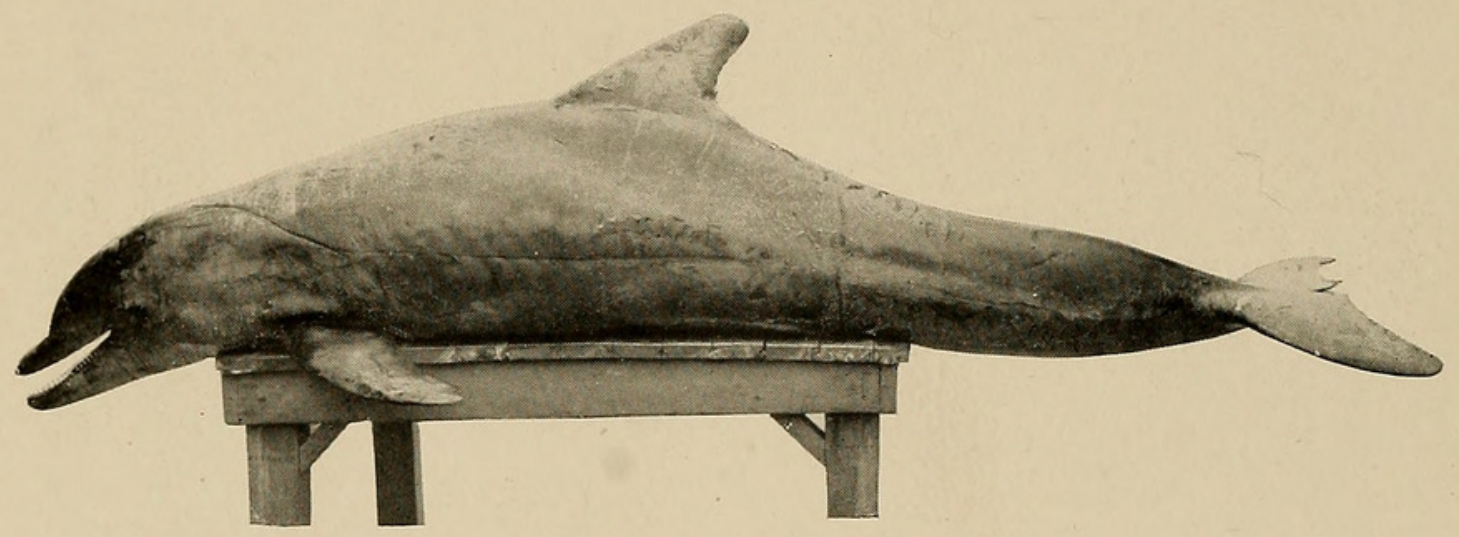

FIG. 9. TURSIOPS TRUNCATUS

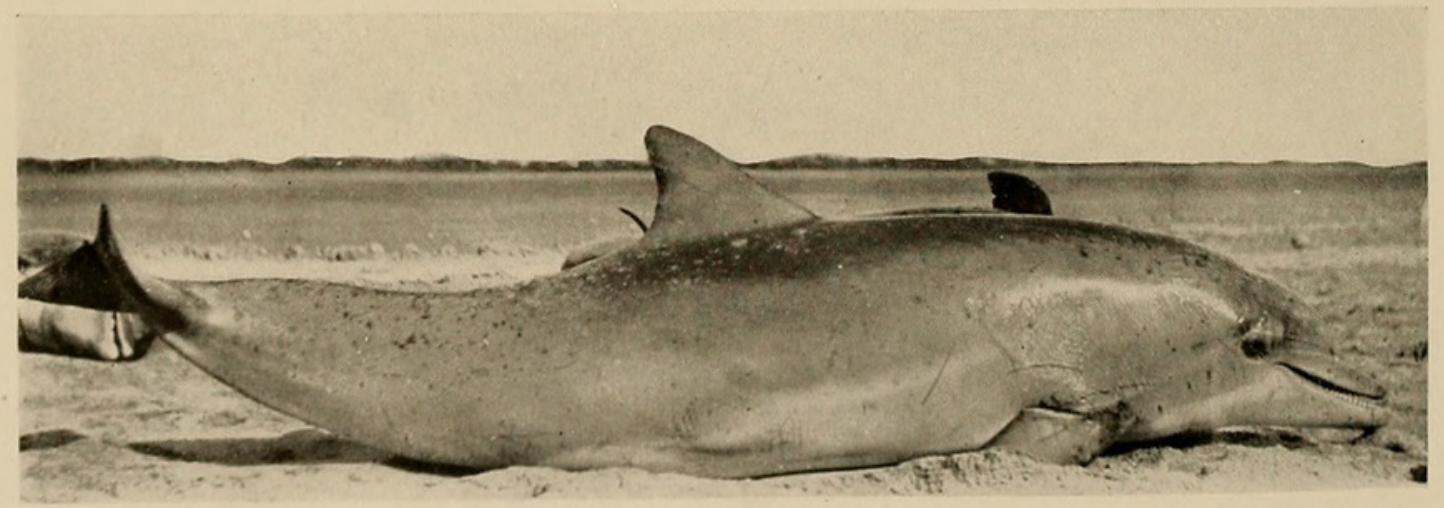

FIG. 10. TURSIOPS TRUNCATUS 


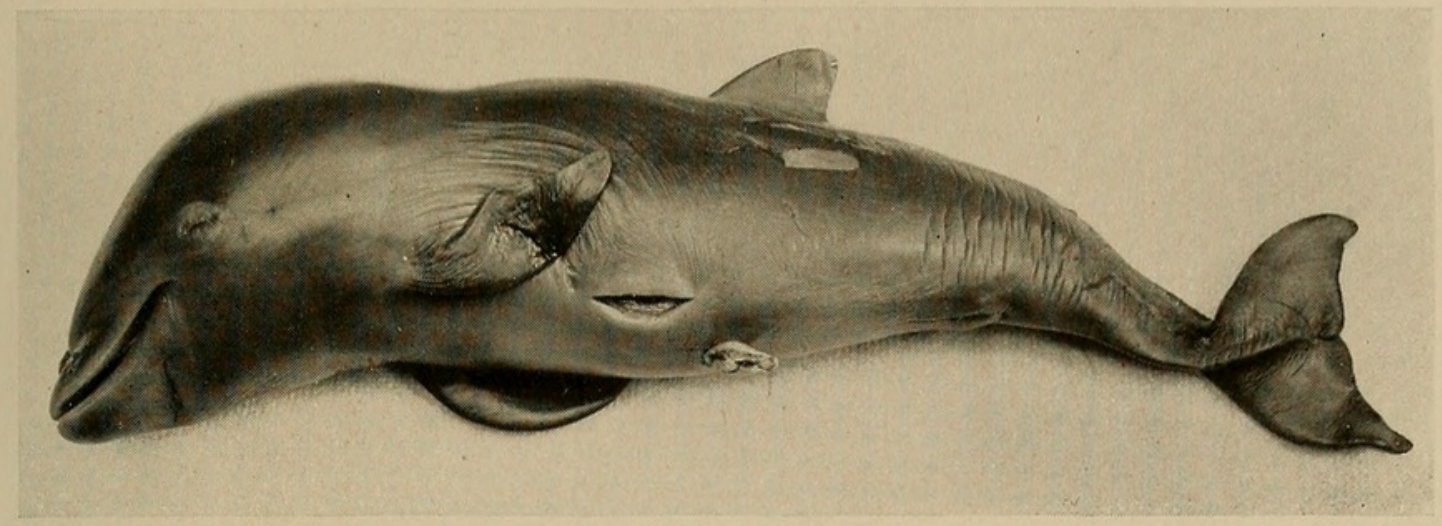

FIG. 11. FOETAL PORPOISE (TURSIOPS TRUNCATUS) 15 INCHES LONG Hatteras, November 12, 1913.

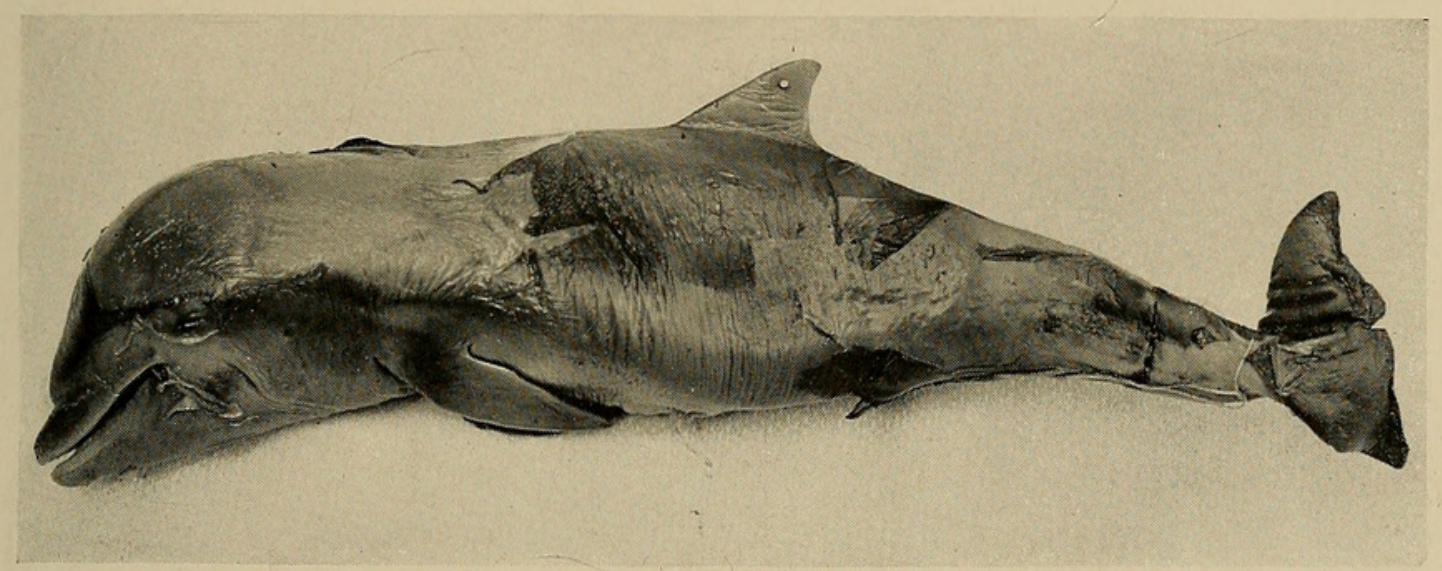

FIG. 12. FOETAL PORPOISE (TURSIOPS TRUNCATUS) $12 \frac{1}{2}$ INCHES LONG Hatteras, November 12, 1913.

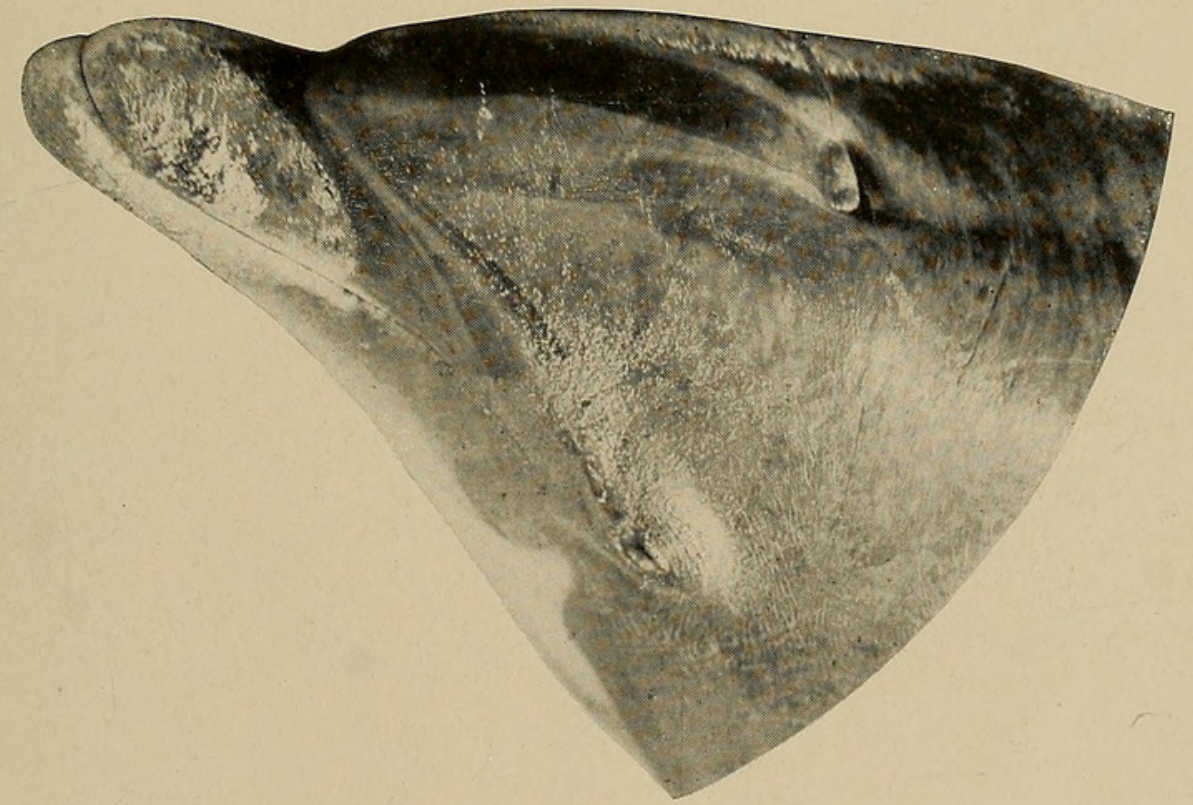

FIG. 13. HEAD OF TURSIOPS TRUNCATUS (Sand should have been wiped off.) 


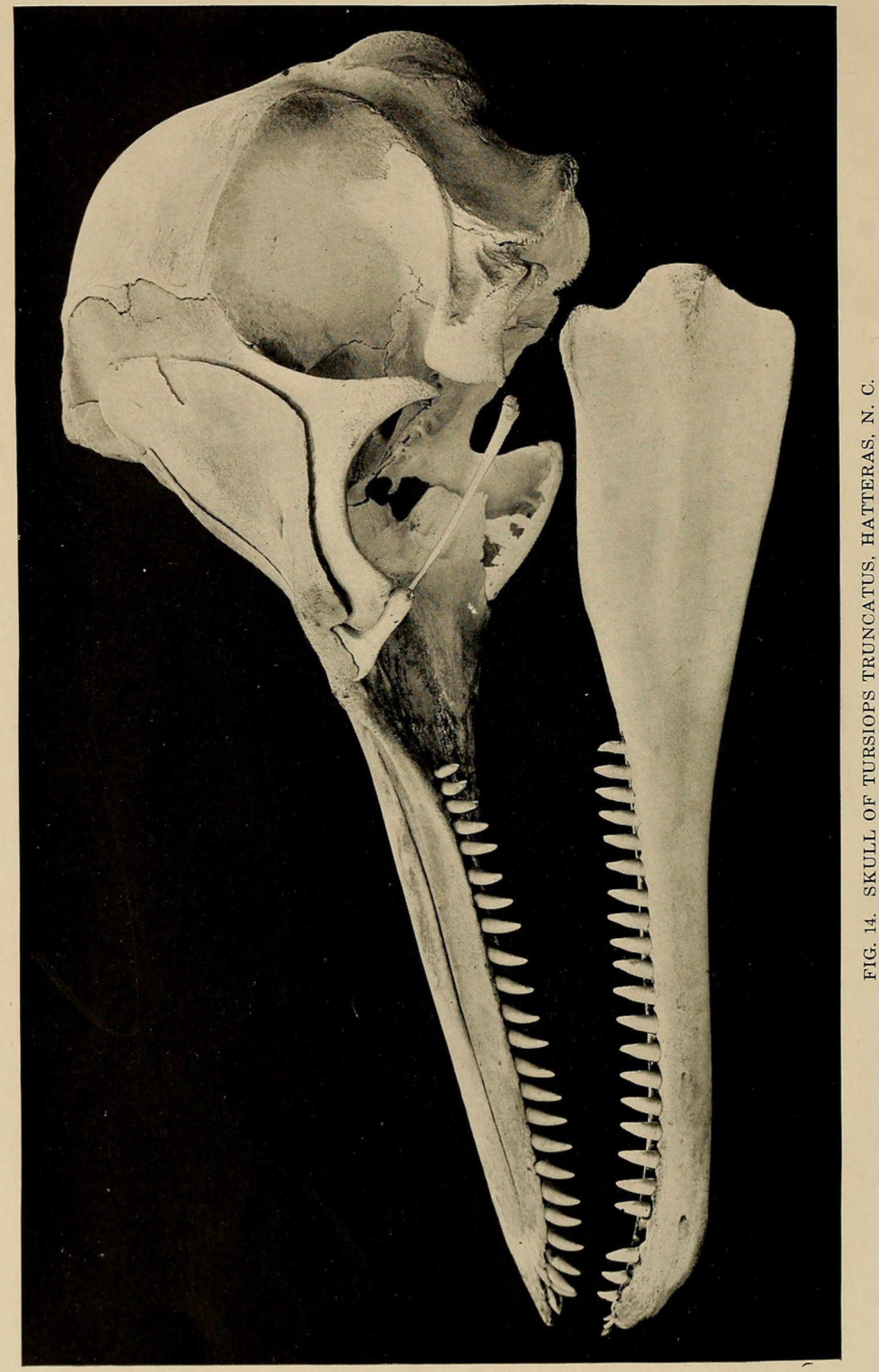




\section{$2 \mathrm{BHL}$ Biodiversity Heritage Library}

Townsend, Charles Haskins. 1914. "The porpoise in captivity." Zoologica: scientific contributions of the New York Zoological Society 1(16), 289-299. https://doi.org/10.5962/p.203801.

View This Item Online: $\underline{\text { https://www.biodiversitylibrary.org/item/97326 }}$

DOI: https://doi.org/10.5962/p.203801

Permalink: https://www.biodiversitylibrary.org/partpdf/203801

\section{Holding Institution}

Harvard University, Museum of Comparative Zoology, Ernst Mayr Library

\section{Sponsored by}

Harvard University, Museum of Comparative Zoology, Ernst Mayr Library

\section{Copyright \& Reuse}

Copyright Status: Public domain. The BHL considers that this work is no longer under copyright protection.

This document was created from content at the Biodiversity Heritage Library, the world's largest open access digital library for biodiversity literature and archives. Visit BHL at https://www.biodiversitylibrary.org. 